\title{
TINJAUAN MAQASHID AL-SYARI'AH TERHADAP PEMBEBASAN NARAPIDANA ASIMILASI DI LEMBAGA PEMASYARAKATAN KELAS IIB PATI
}

\author{
Nor Kholifatur Rosyidah', Aristoni ${ }^{2}$ \\ Mahasiswa Prodi Hukum Keluarga Islam Fakultas Syariah IAIN Kudus ${ }^{1}$, \\ Institut Agama Islam Negeri Kudus ${ }^{2}$ \\ Email:nrosyidah197@yahoo.com, Email :aristoni@iainkudus.ac.id
}

\begin{abstract}
Assimilation is a process of fostering prisoners whose implementation is by assimilation of prisoners in the community with the aim of restoring the social functions of prisoners back in community life. During the Covid-19 pandemic, assimilation was given because there were excess occupancy in Correctional Institutions so it was feared that inmates would be exposed to Covid-19. This study aims to identify and explain the implementation of assimilation for prisoners in terms of maqashid al-syari'ah. For this reason, this study uses a type of empirical juridical research with a qualitative approach. Sources of data used in the form of primary data and secondary data, and data collection techniques using observation and interviews. As for the data analysis technique, this research used qualitative descriptive. The result of the research is that the implementation of assimilation for prisoners is not necessarily given to all prisoners, but must meet the substantive and administrative requirements as stipulated in the provisions of Article 4 and Article 5 of the Regulation of the Minister of Law and Human Rights Number 32 of 2020. In the review of maqashid al-syari' Ah, the assimilation policy for prisoners can be said to be directly proportional to the value of maintaining hifdz ad-din (maintaining religion), hifdz an-nafs (maintaining the soul), hifdz al-al-aql (maintaining reason), hifdz al-nasl (maintaining offspring), hifdz al-mal (maintaining property).
\end{abstract}

Keywords : Assimilation, Maqashid al-Shari'ah, Correctional Institution

\begin{abstract}
Abstrak
Asimilasi merupakan proses dari suatu pembinaan narapidana yang pelaksanaannya dengan membaurkan narapidana di lingkungan masyarakat dengan tujuan untuk memulihkan fungsi sosial narapidana kembali di dalam kehidupan masyarakat. Pada masa pandemi Covid-19, asimilasi diberikan karena terdapat kelebihan hunian di Lembaga Pemasyarakatan sehingga dikhawatirkan Narapidana akan terpapar dari Covid-19. Penelitian ini bertujuan untuk mengetahui dan menjelaskan pelaksanaan pemberian asimilasi bagi Narapidana ditinjau dari maqashid al-syari'ah. Untuk itu penelitian ini menggunakan jenis penelitian yuridis empiris dengan pendekatan kualitatif. Sumber data yang digunakan berupa data primer dan data sekunder, dan teknik pengumpulan data menggunakan observasi dan wawacara. Sedangkan untuk teknik analisis data, penelitian ini menggunakan deskriptif kualitatif. Hasil penelitian ialah pelaksanaan asimilasi bagi Narapidana tidak serta merta diberikan kepada semua Narapidana, melainkan harus memenuhi persyaratan
\end{abstract}


substantif dan adminsitratif sebagaimana diatur dalam ketentuan Pasal 4 dan Pasal 5 Peraturan Menteri Hukum dan Hak Asasi Manusia Nomor 32 Tahun 2020. Dalam tinjauan maqashid al-syari'ah, kebijakan asimilasi bagi Narapidana dapat dikatakan berbanding lurus dengan nilai menjaga hifdz ad-din (memelihara agama), hifdz an-nafs (memelihara jiwa), hifdz al-al-aql (memelihara akal), hifdz alnasl (memelihara keturunan), hifdz al-mal (memelihara harta).

Kata Kunci : Asimilasi, Maqashid al-Syari'ah, Lembaga Pemasyarakatan

\section{PENDAHULUAN}

Sejak ditetapkannya Corona Virus Disease yang selanjutnya disebut Covid-19 sebagai bencana nasional non-alam, berbagai kebijakan dilakukan oleh pemerintah Indonesia dalam rangka pencegahan dan penanggulangan laju penyebaran virus tersebut seperti pola hidup sehat, menjaga jarak, memakai masker dan pembatasan sosial berskala besar kepada seluruh masyarakat. Pada ranah hukum, pemerintah Indonesia melalui Kementerian Hukum dan Hak Asasi Manusia juga mengeluarkan program asimilasi kepada warga binaan pemasyarakatan dengan menerbitkan Peraturan Menteri Hukum dan Hak Asasi Manusia Nomor 10 Tahun 2020 tentang Syarat Pemberian Asimilasi dan Hak Integrasi Bagi Narapidana dan Anak dalam Rangka Pencegahan dan Penanggulangan Penyebaran Covid-19 (Saputra, 2021: 2477).

Pasal 1 ayat (3) disebutkan bahwa Asimilasi ialah proses pembinaan Narapidana dan Anak yang dilaksanakan dengan membaurkan Narapidana dan Anak dalam kehidupan masyarakat. Sementara itu, menurut Peraturan Pemerintah Nomor 31 Tahun 1999 tentang Pembinaan dan Pembimbingan Warga Binaan Pemasyarakat, Pasal 1 ayat (9) dikatakan bahwa Asimilasi merupakan proses pembinaan narapidana dan anak didik pemasyarakatan yang dilaksanakan dengan membaurkan narapidana dan anak didik pemasyarakatan dalam kehidupan masyarakat. Adapun proses pembinaan sebagaimana dimaksud dalam Peraturan Pemerintah ini adalah suatu aktivitas dalam rangka meningkatkan ketaqwaan kepada Tuhan Yang Maha Esa, intelektual, sikap dan perilaku, profesional, kesehatan jasmani dan rohani Narapidana dan Anak Didik pemasyarakatan.

Setidaknya ada beberapa hal yang menjadi pertimbangan pemerintah dalam menerbitkan Peraturan Menteri Hukum dan Hak Asasi Manusia Nomor 10 Tahun 2020. Pertama, institusi baik Lembaga Pemasyarakatan maupun Rumah Tahanan pada dasarnya memiliki tingkat hunian yang tinggi sehingga di masa pandemi ini sangat rentan terhadap penularan dan penyebaran Covid-19. Kedua, untuk penyelamatan Narapidana dan Anak dari terpapar Covid-19 (Anwar, 2020: 103). Dari pertimbangan itulah pemerintah mengeluarkan kebijakan pembebasan Narapidana melalui asimilasi dan integrasi sebagai 
perwujudan dalam pencegahan dan penanggulangan penyebaran Covid19 sebagaimana dapat dilihat dari konsideran Peraturan Menteri ini.

Beberapa pertimbangan tersebut di atas, jika dilihat dari aspek tujuannya sesungguhnya kebijakan pemerintah mengenai program asimilasi bagi Narapidana dapat dikatakan bernilai kebaikan, artinya kebijakan pemerintah tersebut sebagai upaya hukum dalam melindungi jiwa seseorang dari ancaman bahaya Covid-19 dan agar isi hunian institusi sebagaimana disebutkan di atas berkurang sehingga Covid-19 tidak menyebar luas (Baihaki \& Nurhalimah, 2020: 226). Sejauh ini Narapidana dan anak yang mendapatkan program asimiliasi telah mencapai lebih dari 69.500 (lapassemarang.kemenkumham.go.id).

Berdasarkan penelitian awal (observasi) di Lembaga Pemasyarakatan Kelas IIB Pati, Narapidana yang mendapatkan program asimilasi mencapai 280 (Data Catatan Lembaga Pemasyarakatan Kelas IIB Pati). Namun demikian, oleh sebagian masyarakat justru beranggapan bahwa kebijakan pemerintah mengenai program asimilasi tidaklah tepat dan justru menimbulkan masalah baru dalam situasi pandemi Covid-19 ini. Anggapan tersebut tentunya tidak sepenuhnya salah mengingat dalam situasi yang serba sulit terutama dari aspek ekonomi akibat pandemi Covid-19 memungkinkan Narapidana melakukan kejahatan kembali saat dibebaskan dikarenakan kesulitan mencari pekerjaan dalam memenuhi kebutuhan hidupnya, sehingga pembebasan Narapidana program asimilasi menimbulkan keresahan di masyarakat. Oleh karena itu program asimilasi perlu dilakukan kajian lebih mendalam terutama dari aspek kemanfaatan. Dari gambaran realitas tersebut itulah, penelitian ini mencoba mengkaji pembebasan Narapidana melalui asimilasi di Lembaga Pemasyarakatan ditinjau dari maqashid al-syari'ah.

Anwar (2020) dalam penelitiannya dengan judul "Asimilasi dan Peningkatan Kriminalitas di Tengah Pembatasan Sosial Berskala Besar Pandemi Corona", di mana hasil penelitiannya menunjukkan bahwa kebijakan asimilasi terhadap eks Narapidana dinilai tidak efektif sebab kebijakan tersebut sangat berpotensi terhadap meningkatnya angka kriminalitas disemua daerah apalagi situasi yang serba sulit sekarang ini, dengan kondisi tersebut memungkinkan eks Narapidana nekat berulah lagi. Sementara itu, Bayu Rizky (2020) dalam penelitiannya dengan judul "Dampak Positif Kebijakan Asimilasi dan Integrasi Bagi Narapidana dalam Pencegahan dan Penanggulangan Covid-19" menyatakan bahwa kebijakan pemerintah tentang progam asimilasi berimplikasi signifikan terhadap pencegahan penyebaran Covid-19 dalam lapas. Manfaat dari kebijakan tersebut juga mampu menghemat anggaran negara mencapai ratusan miliar hal ini dikarenakan dengan berkurangnya jumlah Narapidana di Lembaga Pemasyarakatan. 
Baihaki \& Nurhalimah (2020) dalam penelitiannya dengan judul "Prinisp Proporsionalitas dalam Kebijakan Asimilasi dan Integrasi Narapidana Pasa Masa Pandemi Covid-19", hasil penelitiannya menunjukkan bahwa kebijakan integrasi dan asimilasi dengan pendekatan prinsip proporsionalitas dapat dikatakan sebagai kebijakan yang progresif, meskipun demikian kebijakan tersebut diperlukan instrumen dan evaluasi. Berbeda dengan penelitian yang dilakukan oleh Umronah (2020), dalam penelitiannya menunjukkan bahwa pembebasan eks Narapidana diperlukan optimalisasi pengawasan secara intensif oleh lembaga berwenang dalam hal ini Balai Pemasyarakat sebagai upaya pencegahan penyebaran Covid-19 dan agar eks Narapidana tidak melakukan pelanggaran hukum lagi. Lebih lanjut, Umronah juga mengatakan bahwa apabila pengawasan terhadap eks Narapidana tidak dilakukan secara optimal, maka akan berimplikasi terhadap dua hal yaitu eks Narapidana program asimilasi mengulangi kejahatannya dan menimbulkan kekhawatiran di masyarakat.

Beberapa hasil penelitian terdahulu di atas setidaknya dapat dijadikan sebagai kajian pembanding dalam penelitian ini sehingga akan diketahui sisi perbedaan (distingsi) maupun persamaan, begitu juga agar tidak terjadi pengulangan dalam kajian. Persamaan penelitian terdahulu dengan penelitian ini adalah sama-sama mengkaji mengenai masalah asimilasi bagi Narapidana di masa pandemi Covid-19, sedangkan perbedaanya adalah metode yang digunakan penelitian terdahulu di atas berbasis yuridis normatis, sementara penelitian ini menggunakan metode penelitian yuridis empiris.

Selain itu penelitian ini menfokuskan pada ranah kajian pembebasan Narapidana asimilasi di Lembaga Pemasyarakatan Kelas IIB Pati ditinjau dari perspektif maqashid al-syari'ah. Adapaun maksud penulis mengunakan perspektif maqashid al-syari'ah ialah untuk mengetahui apakah kebijakan asimilasi yang dikeluarkan oleh pemerintah melalui Kementerian Hukun dan Hak Asasi Manusia yaitu Peraturan Menteri Hukum dan Hak Asasi Manusia Republik Indonesia Nomor 10 Tahun 2020 memiliki relevansi maslahat atau esensi tujuan penetapan hukum Islam atau yang dikenal dengan maqashid al-syari'ah ataukah tidak. Esensi tujuan dari maqashid al-syari'ah itu sendiri ialah untuk merealisasikan kebaikan dan menghindarkan keburukan atau menarik kemanfaatan dan menolak kemadlaratan. Meskipun secara teoretis dipahami bahwa sebagian kalangan menilai bahwa antara konsep hukum positif dengan konsep hukum Islam keduanya tidaklah dapat disamakan, hal tersebut dikarenakan perbedaan sumber yang digunakan. Penelitian ini bertujuan untuk mendiskripsikan dan menjelaskan tinjauan maqashid al-syari'ah terhadap pelaksanaan pembebasan Narapidana asimilasi di Lembaga Pemasyarakatan Kelas IIB Pati. 


\section{METODE PENELITIAN}

Penelitian ini menggunakan metode pendekatan yuridis empiris, yaitu penelitian hukum yang berkaitan dengan implementasi ketentuan hukum normatif yang senyatanya terjadi dalam kehidupan masyarakat dimana sumber datanya diperoleh dari lapangan yang menjadi obyek sasaran penelitian yakni tempat terjadinya suatu gejala (Sugono, 2003: 44). Sedangkan basis pendekatan penelitiannya adalah kualitatif. Sumber Data yang digunakan berupa data primer dan data sekunder. Data primer berupa hasil wawancara secara langsung dengan informan yaitu Kalapas Kelas IIB Pati, Kepala Seksi Binadik, Kasubsi Registrasi dan Bimkemas.

Sedangkan data sekunder dalam penelitian ini diantaranya artikel jurnal, buku-buku hukum, majalah hukum, peraturan perundangundangan dan lainnya. Teknik pengumpulan data berupa observasi, wawancara. Adapun metode analisis data yang digunakan dalam penelitian ini adalah diskriptif kualitatif. Alasan penulis menggunakan metode analisis tersebut adalah memudahkan dalam menjelaskan serta mendeskripsikan keadaan senyatanya di lapangan khususnya mengenai pelaksanaan pembebasan narapidana di Lembaga Pemasyarakatan Kelas IIB Pati.

\section{PEMBAHASAN}

\section{Pelaksanaan Asimilasi Narapidana di Lembaga Pemasyarakatan Kelas IIB Pati di Tengah Pandemi Covid-19}

Pandemi Covid-19 ditetapkan sebagai bencana nasional melalui Keputusan Presiden Nomor 12 Tahun 2020 tentang Penetapan Bencana Non Alam Penyebaran Covid-19 pada tanggal 14 Maret tahun 2020 (Wibowo, 2020: 5). Penyebaran virus corona ini berlangsung sangat cepat, sehingga menimbulkan kekhawatiran bagi pemerintah salah satunya terhadap warga binaan yang ada di dalam Lembaga Pemasyarakatan yang mengalami kelebihan penghuni. Kondisi tersebut mendorong pemerintah melalui Kementerian Hukum dan Hak Asasi Manusia menerbitkan Peraturan Menteri Nomor 10 Tahun 2020 sebagaimana telah diubah dengan Peraturan Menteri Nomor 32 Tahun 2020, dengan tujuan untuk mencegah penularan Covid-19 di dalam Lembaga Pemasyarakatan di Indonesia agar narapidana tetap terjamin hak hidupnya melalui program asimilasi (Umronah, 2020: 2).

Menurut Soekanto, asimilasi merupakan proses pembauran atau percampuran antara dua kebudayaan yang mempunyai unsur berbeda sehingga menjadi corak sehingga menghasilkan kebudayaan baru yang diresapi dengan cita-cita, nilai dan tujuan dari unsur-unsur yang berbeda dengan sebelumnya (Soekanto, 2009: 31) Sedangkan, menurut P. Hariyono mengutip dari pendapat Milton Gordon menjelaskan bahwa asimilasi adalah suatu dimensi kehidupan dengan melibatkan banyak dimensi 
kehidupan sebagai proses sosial yang dilakukan oleh individu atau kelompok mayoritas maupun minoritas yang berkaitan antara satu dengan lainnya (Hariyono, 1994: 15). Sejalan dengan pendapat tersebut, R. Achmad berpendapat bahwa asimilasi tehadap narapidana sesungguhnya dapat dilaksanakan di tengah-tengah kelompok masyarakat secara berkelanjutan atau terus menerus baik individu ataupun kelompok, karena terdapat perbedaan antara kehidupan di dalam Lembaga Pemasyarakatan dengan di luar Lembaga Pemasyarakatan (R. Achmad S, 1992: 13).

Asimilasi menurut Peraturan Menteri Hukum dan Hak Asasi Manusia Nomor 21 Tahun 2013 tentang Syarat dan Tata Cara Pemberian Remisi, Asimilasi, Cuti Mengunjungi Keluarga, Pembebasan Bersyarat, Cuti Menjelang Bebas dan Cuti Bersyarat merupakan suatu proses pembinaan dengan cara membaurkan narapidana dan anak didik pemasyarakatan di dalam kehidupan masyarakat yang bertujuan untuk mempersiapkan narapidana atau warga binaan untuk kembali menjalani kehidupan yang lebih baik di masyarakat. Berangkat dari pengertian asimilasi tersebut, maka dalam tataran praktis, asimilasi Narapidana sangat penting umtuk segera dilaksanakan di tengah kelompok masyarakat karena diharapkan Narapidana dapat meresapi kebudayaan atau kebiasaan yang ada dalam masyarakat tanpa merasa dikucilkan dengan status narapidana tersebut.

Berdasarkan data penelitian, kondisi di Lembaga Pemasyarakatan Kelas IIB Pati mempunyai kapasitas 197 penghuni. Terhitung pada tanggal 31 Januari 2021 Lembaga Pemasyarakatan Kelas IIB Pati mempunyai penghuni sebanyak 365 orang yang terdiri dari 300 orang narapidana dan 65 orang tahanan. Sehingga mengalami over capacity sebanyak 220\%. Hunian narapidana terdiri dari 20 kamar, setiap kamar mempunyai ukuran yang berbeda-beda tergantung kapasitas hunian dengan tempat tidur beralaskan matras (Dokumen dari Data Catatan Lembaga Pemasyarakatan Kelas IIB Pati).

Salah satu upaya untuk tetap menjaga keselamatan Narapidana ditengah pandemi Covid-19, Lembaga Pemasyarakatan Kelas IIB Pati melakukan beberapa langkah-langkah preventif diantaranya: pertama, tidak melayani kunjungan tatap muka terhadap narapidana sejak tanggal 19 Maret 2020, kunjungan hanya dilayani melalui video call, namun pihak keluarga masih dibolehkan untuk mengirim barang atau makanan kepada narapidana melalui perizinan petugas. Kedua, Menyiapkan vitamin, tempat cuci tangan serta hand sanitizer di setiap ruangan. Ketiga, Melakukan penyemprotan 2 kali seminggu ke semua ruangan termasuk sel tahanan. Keempat, menyiapkan pembinaan rohani secara virtual. Adapun langkah-langkah tersebut dilakukan agar Narapdana di dalam Lembaga Pemasyarakatan tidak terpapar Covid-19 sesuai dengan anjuran 
pemerintah (Topan Ahmad Hadian, Kepala Seksi Binadik dan Giatja Lapas IIB Pati, Wawancara, 2021).

Pada prinsipnya pemberian asimilasi kepada Narapidana di Lembaga Pemasyarakatan Kelas IIB Pati didasarkan pada aturan yang berlaku. Hal tersebut disampaikan oleh Hadian saat diwawancarai, kepada penulis mengatakan bahwa "Pemberian asimilasi kepada Narapidana di Lembaga Pemasyarakatan Kelas IIB Pati dilakukan berdasarkan kebijakan pemerintah, namun dalam tataran pelaksanaannya dapat dikategorikan ke dalam dua hal, yaitu pemberian asimilasi di bulam April sampai dengan Desember 2020 merujuk pada Peraturan Menteri Hukum dan HAM Nomor 10 Tahun 2020, sedangkan pada bulan Januari sampai dengan bulan Maret 2021 merujuk pada Peratuan Menteri Hukum dan HAM Nomor 32 Tahun 2020 tentang Perubahan Atas Peraturan Peraturan Menteri Hukum dan HAM Nomor 10 Tahun 2020 tentang Syarat dan Tata Cara Pemberian Asimilasi, Pembebasan Bersyarat, Cuti Menjelang Bebas, dan Cuti Bersyarat bagi Narapidana dan Anak dalam Rangka Mencegah dan Penanggulangan Penyebaran Covid-19".

Selanjutnya, ia juga menambahkan bahwa dalam pelaksanaan pemberian asimilas kepada Narapidana dilakukan dengan mempertimbangan terpenuhinya dua persyaratan yaitu syarat substantif dan syarat administratif. Syarat substantif meliputi: pertama, Narapidana berkelakuan baik dibuktikan dengan tidak dalam menjalani hukuman disiplin dalam waktu enam bulan terakhir. Kedua, aktif mengikuti program pembinaan dengan baik, dan ketiga, telah menjalani $1 / 2$ masa pidana, dan apabila Narapidana yang tidak memenuhi jangka waktu tersebut tidak dapat mendapat asimilasi.

Sedangkan syarat yang bersifat administratif meliputi: pertama, lembar petikan putusan hakim dan berita acara pelaksanaan putusan dari pengadilan. Kedua, Surat bukti pembayaran lunas uang denda atau uang pengganti yang ditentukan oleh putusan pengadilan atau melaksanakan subsider pengganti denda yang dilaksanakan di rumah dalam pengawasan Bapas dengan melampirkan surat pernyataan tidak mampu membayar denda kepada kejaksaan. Ketiga, Laporan yang ditandatangani Kepala Lembaga Pemasyarakatan mengenai perkembangan pembinaan.

Keempat, salinan register F dari Kepala Lembaga Pemasyarakatan. Kelima, salinan daftar perubahan dari Kepala Lembaga Pemasyarakatan. Keenam, surat pernyataan tidak sedang melakukan pelanggaran dan bersedia tinggal di rumah dan menjalankan protokol kesehatan untuk pencegahan Covid-19. Ketujuh, surat keterangan dari lembaga penegak hukum bahwa tidak terlibat tindak pidana lain. Kedelapan, laporan penelitian kemasyarakatan (Litmas) yang disusun oleh pembimbing kemasyarakatan yang ditandatangani oleh Kepala Balai Pemasyarakatan. 
Kesembilan, surat penjamin dari pihak keluarga atau pembimbing kemasyarakatan.

Selain kedua syarat tersebut di atas, terdapat beberapa mekanisme dalam pemberian asimilasi kepada Narapidana di Lembaga Pemasyarakatan Kelas IIB Pati sesuai dengan ketentuan Pasal 7 Peraturan Menteri Hakum dan Hak Asasi Manusia Nomor 32 Tahun 2020, yaitu: pertama, pemberian asimilasi dilakasanakan dengan cara melalui sistem informasi pemasyarakatan yang sudah terintegrasi dengan kantor wilayah, pelaksana teknis pemasyarakatan, serta dengan Direktorat Jenderal. Kedua, apabila sistem tersebut tidak dapat dilakukan, maka asimilasi dapat dilaksanakan degan cara manual oleh Kepala Lapas atau LKPA.

Berdasarkan data yang berhasil dihimpun penulis dilapangan diketahui bahwa Narapidana di Lembaga Pemasyarakatan Kelas IIB Pati yang memperoleh asimilasi sesuai Peraturan Menteri Hukum dan Hak Asasi Manusia Nomor 10 Tahun 2020, dari bulan April sampai dengan bulan Desember 2020 sebanyak 280 Narapidana dengan perincian yaitu bulan April 125 (seratus dua puluh lima) Narapidana, Mei 49 (empat puluh sembilan) Narapidana, Juni 25 (dua pluh lima) Narapidana, Juli 14 (empat belas) Narapidana, Agustus 24 (dua puluh empat) Narapidana, September 9 (sembilan) Narapidana, Oktober 10 (sepuluh) Narapidana, November 15 (lima belas) Narapidana, dan Desember 9 (sembilan) Narapidana. Selanjutnya, untuk Narapidana yang mendapatkan asimilasi sesuai Peraturan Menteri Hukum dan Hak Asasi Manusia Nomor 32 Tahun 2020, dari bulan Januari sampai dengan bulan Maret sebanyak 52 Narapidana dengan perincian yaitu bulan Januari 26 (dua puluh enam) Narapidana, Februari 13 (tiga belas) Narapidana, dan Maret 13 (tiga belas) Narapidana.

Penting untuk diketahui bersama bahwa sebelum Narapidana mendapat asimilasi di rumah, narapidana diwajibkan untuk mengikuti pembinaan yang ada di Lembaga Pemasyarakatan Kelas IIB Pati. Dalam kegiatan pembinaan tersebut, Narapidana juga diberikan keterampilan kerja dengan tujuan agar dimasa pandemi Covid-19 ini mereka memiliki bekal untuk kembali dimasyarakat dengan membuka usaha baru sehingga tidak mengulangi kejahatannya lagi dan tidak meresahkan masyarakat. Meskipun tidak dipungkiri masih terdapat beberapa warga binaan pemasyarakatan setelah mendapat asimilasi ia mengulangi kejahatannya lagi seperti disampaikan oleh Kismiyanto saat diwawancara penulis, beliau mengatakan bahwa "dari jumlah Narapidana yang mendapatkan pembebasan melalui asimilasi di Lembaga Pemasyarakatan Kelas IIB Pati ada 3 (tiga) eks Narapidana yang mengulangi tindak pidananya (residivis)" (Kismiyanto, Kasubsi Registrasi dan Bimkemas, Wawancara, 2021). 
Selain tujuan pembinaaan seperti disampaikan di atas, bahwa pembinaan terhadap Narapidana yang akan memperoleh asimilasi juga bertujuan agar ia menjadi pribadi yang lebih baik dari yang sebelumnya sehingga memiliki peningkatan dalam kualitas hidupnya dan menjadi manusia yang bermanfaat ditengah-tengah masyarakat (Agus Supriyadi, Pengelola Pembinaan Kepribadian, Wawancara, 2021). Oleh karena itu, apabila narapidana yang sedang melaksanakan program asimilasi melakukan pelanggaran, maka mendapat vonis dari putusan pengadilan terbaru dari hasil tindak pidana yang dilakukannya kemudian ditambah dengan $1 / 2$ masa pidananya yang mendapat remisi sebelumnya, tentunya berdasarkan proses yang sudah ditetapkan dalam peraturan perundangundangan serta tidak mendapatkan hak-hak narapidana dalam kurun waktu 1 tahun.

Terdapat tiga macam bentuk asimilasi yang dilakukan di Lembaga Pemasyarakatan Kelas IIB Pati, yaitu asimilasi yang dilakukan di dalam Lembaga Pemasyarakatan, asimilasi di luar Lembaga Pemasyarakatan dan asimilasi dengan pihak ketiga, dalam hal ini Lembaga Pemasyarakatan Kelas IIB Pati melakukannya dengan Kementerian Agama Kabupaten Pati (Topan Ahmad Hadian, Kepala Seksi Binadik dan Giatja Lapas IIB Pati, Wawancara, 2021). Namun demikian, dalam tataran prakteknya, Pelaksanaan pemberian asimilasi kepada Narapidana oleh Lembaga Pemasyarakatan Kelas IIB mengalami hambatan terutama asimilasi di luar Lembaga Pemasyarakatan.

Beberapa hambatan tersebut, yaitu pertama, ketidakjelasan alamat yang dituju oleh narapidana bagi yang berdomisili luar Kabupaten Pati bahkan di luar Provinsi Jawa Tengah. Kedua, keterlambatan dalam pemenuhan berkas sehingga proses yang dibutuhkan memerlukan waktu yang cukup lama. Ketiga, kurangnya sikap positif dari masyarakat luar dalam upaya penerimaan narapidana yang mendapat pembebasan di lingkungannya.

Selanjutnya berdasarkan paparan data dan informasi di atas, menurut analisa penulis bahwa Lembaga Pemasyarakatan Kelas IIB Pati telah merespon dengan baik kebijakan pemerintah dengan mengimplementasikan Peraturan Menteri Hukum dan Hak Asasi Manusia Nomor 10 Tahun 2020 Juncto Peraturan Menteri Hukum dan Hak Asasi Manusia Nomor 32 Tahun 2020 dalam rangka pencegahan dan penanggulangan terhadap penyebaran Covid-19 yang semakin hari semakin mengkhawatirkan, meskipun sebagian kalangan masyarakat ada yang tidak setuju dengan kebijakan pemerintah mengenai program asimilasi ditengah pandemi Covid-19 tersebut. Jika dilihat dari segi prosedur yang dijalankannya, Lembaga Pemasyarakatan tersebut telah melaksanakan pemberian asimilasi kepada Narapidana sesuai regulasi 
yang ada yaitu sesuai dengan ketentuan Pasal 4 dan Pasal 5 Peraturan Menteri Hukum dan Hak Asasi Manusia Nomor 32 Tahun 2020.

Terlepas dari itu semua, menurut penulis hal yang lebih penting di sini adalah sejauhmana lembaga berwenang (Balai Pemasyarakatan) dalam hal ini pembimbing kemasyarakatan mampu melakukan pengawasan secara optimal terhadap eks Narapidana yang memperoleh asimilasi dan benar-benar mampu menjamin yang bersangkutan (eks Narapidana) tersebut tidak mengulangi tindak pidana lagi sebagaimana yang telah dikhawatiran masyarakat. Meski disadari pengawasan terhadap eks Narapidana asimilasi tidak bisa hanya dibebankan kepada pembimbing kemasyarakatan melainkan dibutuhkan keterlibatan masyarakat terutama keluarga eks Narapidana, Pemerintan Desa, dan aparat penegak hukum sehingga apa yang menjadi tujuan dari pengawasan dapat terealisasi. Hal ini sejalan pendapat Rahmasari, dalam penelitiannya mengatakan bahwa keterlibatan masyarakat sangat dibutuhkan dalam merealisasikan keberhasilan dari tujuan pengawasan yang telah ditetapkan, dibutuhkannya keterlibatan masyarakat tersebut dikarenakan pembebasan Narapidana asimilasi muaranya akan kembali ke tengah-tengah kehidupan masyarakat (Rahmasari, 2020: 371)

Tinjauan Maqashid Al-Syari'ah Terhadap Pembebasan Narapidana Melalui Asimilasi di Lembaga Pemasyarakatan Kelas II B Pati

Sebelum mengkaji permasalahan pembebasan Narapidana melalui asimilasi dari sudut pandang maqashid al-syari'ah, maka terlebih dahulu akan dipaparkan konsep maqashid al-syari'ah itu sendiri. Pada dasarnya maqashid al-syari'ah kedudukannya sangat penting kaitannya dalam hukum Islam. Dikatakan sangat penting karena urgensinya didasarkan pada beberapa pertimbangan, antara lain: Pertama, hukum Islam merupakan peraturan yang sumber utamanya berasal dari kitab AlQur'an dan Hadis yang diperuntukkan untuk manusia. Maka dari itu hukum Islam akan selalu dihadapkan dengan perubahan sosial. Kedua, dilihat dari aspek sejarah atau historisnya, sejak zaman Rasulullah SAW dan generasi mujtahid sesudahnya telah menerapkan konsep maqashid alsyari'ah dalam kehidupan sehari-hari. Ketiga, kunci keberhasilan para mujtahid dalam penetapan ijtihadnya adalah maqashid al-syari'ah, karena dijadikan sebagai landasan tujuan hukum dalam penyelesaian persoalan antar manusia (Shidiq, 2009: 31).

Al-Raisuni mendefinisikan maqashid al-syari'ah merupakan tujuan yang telah ditetapkan syariah dalam rangka merealisasikan kemaslahatan untuk seluruh alam (umat manusia). Kemaslahatan sebagaimana yang diungkapkan oleh Raisuni dibatasi dalam 5 (lima) hal yaitu agama, akal, jiwa, keturunan dan harta (Harahap, 2014: 180). Jadi, setiap hal yang 
didasarkan pada kelima hal tersebut dapat dikatakan sebagai kebaikan (maslahat) dan begitu sebaliknya (Shidiq, 2018: 118).

Sejalan dengan al-Raisuni, Imam al-Syatibi sebagaimana dikutip Kamalludin \& Arief , mendefinisikan maqashid al-syari'ah ialah kebaikan (maslahat) yang ditujukan kepada umat manusia. Arti umat manusia di sini tidak hanya terbatas pada umat Islam saja melainkan seluruh umat manusia (Kamalludin \& Arief, 2018: 204). sebagaimana dinyatakan dalam surat al-Anbiya ayat 107:

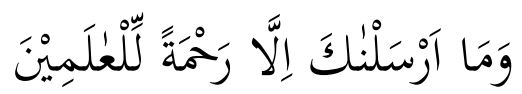

Artinya: "Dan kami tidak mengutusmu (muhammad) kecuali untuk menjadi rahmat bagi seluruh semesta alam" (Q.s.AlAnbiya: 107).

Imam al-Syatibi membagi maqashid al-syari'ah ke dalam tiga tingkatan, yaitu pertama, dharuriyyat (kebutuhan primer), artinya apabila kebutuhan dharuriyyat tidak dilaksankan atau tidak dipenuhi, maka akan menyebabkan keselamatan manusia menjadi terancam atau hancur baik di dunia maupun akhirat. Ada lima unsur pokok yang harus dipenuhi dalam pencapaian maqashid al-syari'ah antara lain meliputi hifdz ad-din (memelihara agama), hifdz an-nafs (memelihara jiwa), hifdz al-al-aql (memelihara akal), hifdz al-nasl (memelihara keturunan), hifdz al-mal (memelihara harta). Kedua, hajiyyat (kebutuhan sekunder), artinya untuk mempermudah atau menghilangkan kesulitan. Jadi apabila Hajiyyat tidak dilaksanakan tidak sampai membahayakan keselamatan, namun akan muncul kesulitan seperti meng-ashar shalat dalam keadaan sedang berpergian jarak jauh. Ketiga, tahsiniyyat (kebutuhan tersier), artinya kebutuhan yang dijadikan sebagai penyempurna atau pelengkap. Apabila Tahsiniyyat tidak dijalankan maka tidak akan menimbulkan kehancuran dan tidak menemui kesulitan (Al-Rasyid, 2016: 72).

Berangkat dari beberapa definisi para ahli di atas, maka dapat disimpulkan bahwa maqashid al-syari'ah adalah tujuan yang ditetapkan dalam hukum Islam yang diperuntukkan seluruh hamba-Nya dalam rangka mewujudkan kebaikan (kemaslahatan) baik di dunia maupun diakhirat. Lantas bagaimana konsep maqashid al-syari'ah melihat pembebasan Narapidana melalui asimilasi seperti di Lembaga Pemasyarakatan Kelas IIB Pati.

Sejak awal kebijakan pemerintah mengenai progam asimilasi dengan menerbitkan Peraturan Menteri Hukum dan Hak Asasi Manusia Nomor 10 Tahun 2020 sebagaimana telah diubah dengan Peraturan Menteri Hukum dan Hak Asasi Manusia Nomor 32 Tahun 2020 bertujuan untuk melindungi kepentingan jiwa warga binaan dari bahaya Covid-19. Dari sini dapat ditarik benang merah bahwa kebijkan program asimilasi tersebut merupakan kebijakan alternatif yang berdimensi pada maslahat 
demi kemanusiaan sebagai akibat dari adanya pandemi Covid-19. Sehingga menurut penulis, secara esensi kebijakan pemerintah mengenai asimilasi terhadap Narapidana sejalan dengan inti dari tujuan maqashid alsyari'ah yaitu bernilai kemaslahatan sebab melindungi jiwa warga binaan di Lembaga Pemasyarakatan. Sehubungan dengan kekhawatiran sebagian masyarakat terhadap eks Narapidana akan berubah kembali hal tersebut dapat dibenarkan, akan tetapi tidak dapat dijustifikasi secara universal sebab pada hakikatnya dalam diri manusia terdapat potensi untuk menjadi manusia yang lebih baik.

Realitas menunjukkan bahwa meskipun penjaa tidak jarang dapat merehabilitasi Narapidana, akan tetapi juga membuat kecenderungan individu lebih jahat dan mengulangi perbuatannya, dan kembali ke penjara. Jika menggunakan penjara sebagai jawaban bagi orang-orang yang ekonominya rendah (miskin) tentu saja tidak hanya merupakan masalah keamanan masyarakat, melainkan juga mengabdikan siklus pemiskinan apalagi di tengah kondisi pandemi Covid-19 sekarang ini, ditambah banyak resiko kesehatan dari kepadatan penjara dari ancaman paparan penyakit Covid-19. Sehingga kebijakan pemberian asimilasi bagi Narapidana merupakan kebijkan alternatif keringan sebagai solusi atas pemasalahan yang dihadapi negara dalam menekan tingginya angka Covid-19.

Kebijakan pemerintah mengenai asimilasi bagi Narapidana jika ditinjau dari maqashid al-syari'ah, sesuai dengan konsep Imam al-Syatibi, maka dapat dikatakan berbanding lurus dengan nilai menjaga hifdz ad-din (memelihara agama), hifdz an-nafs (memelihara jiwa), hifdz al-al-aql (memelihara akal), hifdz al-nasl (memelihara keturunan), hifdz al-mal (memelihara harta). Penulis mencoba memaparkan hubungan pelaksanaan pemberian asimilasi bagi Narapidana ditinjau dari maqashid al-syari'ah, sebagai berikut:

\section{Hifdz ad-din (memelihara agama)}

Pelaksanaan asimilasi di rumah di tengah pandemi Covid-19 ini sangat penting. Dalam hal ini pelaku maupun penegak hukum sudah menjalankan sesuai dengan tujuan dari hukum itu sendiri. Apabila masing-masing pihak sudah melaksanakan hak dan kewajibannya, maka hal ini sudah sesuai dengan prinsip keadilan dan memiliki kesesuaian dengan tujuan syari'at Islam. Asimilasi di rumah yang diterapkan pada masa Covid-19 merupakan bentuk pelaksanaan hukuman yang mendesak yang menjunjung keadilan sesuai peraturan yang diterapkan sekarang ini. Pemberian keringanan masa pidana ini sangat memungkinkan untuk narapidana bisa menjalankan kewajiban terhadap agamanya, seperti apabila statusnya sebagai kepala keluarga, ia akan kembali menjadi imam dalam keluarganya dengan lebih leluasa tanpa kesan perampasan kemerdekaan dan juga dapat meminimalisir 
perilaku yang menistakan agama lain di dalam Lembaga Pemasyarakatan.

2. Hifdz an-nafs (memelihara jiwa)

Dalam menjalani asimilasi di rumah di tengah pandemi Covid-19 sangat penting kaitannya dalam pemeliharaan jiwa, apabila hal ini tidak dilaksanakan maka eksistensi jiwa manusia akan terancam. Perlindungan nyawa adalah alasan utama dari pengeluaran kebijakan asimilasi ini. Pelaksanaan asimilasi di rumah sangat meringankan khususnya bagi pelaku, karena apabila ia sebagai tulang punggung keluarga artinya pelaku dapat memberikan perlindungan terhadap keluarganya, bukan hanya bagi pelaku tetapi korban dan keluarga korban serta penegak hukum juga dapat melindungi dirinya sesuai dengan Pasal 28G ayat (1) Undang-Undang Dasar Negara Republik Indonesia Tahun 1945.

Di samping itu pemeliharaan jiwa di tengah pandemi Covid-19 sesuai dengan Peraturan Menteri Hukum dan Hak Asasi Manusia Nomor 32 Tahun 2020 adalah hal yang harus dilakukan, karena jika kebijakan pemberian asimilasi di rumah ini tidak dilaksanakan, maka Lembaga Pemasyarakatan akan menjadi kuburan massal sebab di dalam Lembaga Pemasyarakatan Kelas IIB Pati sendiri terjadi over capacity sehingga tidak memungkinkan untuk menjaga jarak satu sama lain antara warga binaan.

3. Hifdz al-aql (memelihara akal)

Pemberian asimilasi dengan maksud meringankan masa pidana ini juga akan berdampak positif pada akal. Dari sisi psikologis apabila pemberian asimilasi ini tidak diberikan, maka para narapidana yang terlalu lama mendekam, eksistensi akal akan terancam di dalam Lembaga Pemasyarakatan. Para narapidana akan mengalami stress karena kurangnya interaksi dari luar sehingga dapat menimbulkan beban psikologis dan mengganggu keamanan dalam Lembaga Pemasyarakatan, jika terlalu lama di dalam Lembaga Pemasyarakatan maka yang akan terjadi adalah pengasingan dari masyarakat setelah pelaku dibebaskan, terutama jika narapidana ini adalah seorang pelajar atau ahli pendidikan mengingat sarana dalam memelihara akal berupa ilmu.

4. Hifdz al-nasl (memelihara keturunan)

Alternatif asimilasi di rumah akan sangat bermanfaat bagi individu yaitu pelaku akan dapat berkumpul kembali dengan keluarga dan memenuhi kebutuhan rumah tangga bagi yang berstatus sebagai kepala keluarga sehingga bisa menjaga keturunan (hifdz al-nasl) dengan baik dan juga tentunya akan memberikan penghidupan yang baik terhadap garis keturunannya. Kebebasan yang dimiliki dalam hal ini kewajiban memberi nafkah kepada keluarga dan memberikan 
pendidikan yang baik merupakan salah satu upaya untuk regenerasi manusia yang di syari'atkan oleh agama Islam dengan mengharapkan keturunan yang terhormat agar tidak terjerumus kepada perilaku yang menyimpang dalam Islam, seperti pergaulan bebas.

5. Hifdz al-mal (memelihara harta)

Pemberian asimilasi juga bermanfaat bagi negara yaitu dengan dikeluarkannya narapidana, maka beban dan kas negara akan berkurang dalam menanggung biaya makan dan sarana prasarana bagi narapidana yang berada di dalam Lembaga Pemasyarakatan sehingga uang negara dapat digunakan untuk memenuhi kepentingan lain yang lebih bermanfaat (hifdz al-mal).

Persyaratan substantif dan administratif sebagaimana dalam ketentuan Pasal 4 dan Pasal 5 Peraturan Menteri Hukum dan Hak Asasi Manusia Nomor 32 Tahun 2020 tentang Perubahan Atas Peraturan Menteri Hukum dan Hak Asasi Manusia Nomor 10 Tahun 2020 merupakan wujud selektifitas negara dalam memberikan pemberian asimilasi bagi narapidana telah sesuai dengan prinsip syari'at Islam yaitu maqashid al-syari'ah dan sesuai dengan teori tujuan pemidanaan dalam hukum positif. Ketika narapidana menjalankan masa pidananya di Lembaga Pemasyarakatan, selain harus menanggung beban psikologis, narapidana juga dikhawatirkan tertular penyakit dan teror kematian. Maka dari itu pemberian asimilasi pada masa Covid-19 perspektif maqashid al-syari'ah termasuk kepada kemaslahatan primer (maqashid dharuriyyat), yaitu suatu hal yang sangat dibutuhkan oleh manusia, dan apabila hal ini tidak dilaksanakan maka akan terjadi kerusakan dalam kehidupan manusia. Hal ini sesuai dengan kaidah Fikih yang berbunyi :

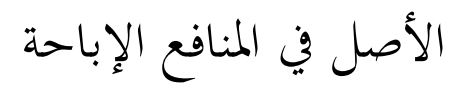

Artinya: "Prinsip dasar pada masalah manfaat adalah boleh".

Kaidah Fikih ini menunjukkan kebolehan dalam menetapkan suatu hukum yang mengedepankan masalah-masalah kemaslahatan atau kemanfaatan yang tidak diatur dalam nash Al-Qur'an atau tidak ada penunjukan makna yang menyerupai atau hampir mendekati masalah tersebut. Dan tidak ada pula pelarangan secara jelas dalam hukum yang terkait permasalahan kemaslahatan yang di dalamnya mengandung keringanan dan kemudahan dalam penetapan hukum. Untuk meminimalisir sikap masyarakat yang kurang menerima keberadaan narapidana asimilasi, maka diperlukan suatu upaya yang dapat meyakinkan masyarakat bahwa narapidana yang mendapat asimilasi tidak serta merta dikeluarkan begitu saja, namun ada tahapan yang harus dijalani sebelum mereka dikeluarkan. 


\section{SIMPULAN}

Berdasarkan uraian pembahasan di atas, penelitian ini dapat disimpulkan bahwa kondisi pandemi Covid-19 di Indonesia telah direspon Pemerintah dengan mengeluarkan beberapa kebijakan hukum salah satunya adalah program asimilasi yang bertujuan untuk mencegah dan menanggulangi penyebaran Covid-19 di Lembaga Pemasyarakatan. Kebijakan tersebut tertuang dalam Peraturan Menteri Hukum dan Hak Asasi Manusia Nomor 10 Tahun 2020 sebagimana telah diubah dengan Peraturan Menteri Hukum dan Hak Asasi Manusia Nomor 32 tahun 2020. Meskipun program tersebut diberikan kepada Narapidana, akan tetapi dalam pelaksanaannya pemberian asimilasi tersebut tidak serta merta diberikan kepada semua Narapidana, melainkan harus memenuhi persyaratan substantif dan administratif sebagaimana telah diatur dalam ketentuan Pasal 4 dan Pasal 5 Peraturan Menteri Hukum dan Hak Asasi Manusia Nomor 32 tahun 2020.

Kebijakan pemberian asimilasi bagi Narapidana merupakan kebijakan alternatif keringan pidana penjara yang berdimensi kemanusiaan sebagi akibat dari penyebaran penyakit Covid-19, sehingga dalam tinjauan maqashid al-syari'ah, kebijakan tersebut berbanding lurus dengan nilai menjaga hifdz ad-din (memelihara agama), hifdz an-nafs (memelihara jiwa), hifdz al-al-aql (memelihara akal), hifdz al-nasl (memelihara keturunan), hifdz al-mal (memelihara harta).

\section{DAFTAR PUSTAKA}

\section{Buku-buku}

Al-Rasyid, H. (2016). Fikih Korupsi: Analisis Politik Uang Indonesia dalam Perspektif Maqashid al Syari'ah. Kencana.

Hariyono. (1994). Pemahaman Menuju Asimilasi Kultural. Pustaka Sinar Harapan.

Soekanto, S. (2009). Sosiologi Suatu Pengantar. Rajawali Press.

Sugono, B. (2003). Metodologi Penelitian Hukum. Raja Grafindo Persada.

\section{Jurnal-jurnal}

Anwar, M. (2020). Asimilasi dan Peningkatan Kriminalitas di Tengah Pembatasan Sosial Berskala Besar Pandemi Corona. 'Adalah; Buletin Hukum Dan Keadialan, 4(1), 101-106. http:/ /journal.uinjkt.ac.id/index.php/adalah/article/view/15504/7 263

Baihaki, M. R., \& Nurhalimah, S. (2020). Prinsip Proporsionalitas Dalam Kebijakan Asimilasi Dan Integrasi Narapidana Pada Masa Pandemi Pandemi Covid-19. Majalah Hukum Nasional, 50(2), 221-240. https:/ / doi.org/10.33331/mhn.v50i2.78 
Harahap, Z. A. A. (2014). Konsep Maqasid Al-Syariah Sebagai Dasar Penetapan Dan Penerapannya Dalam Hukum Islam Menurut 'Izzuddin Bin 'Abd Al-Salam. Tazkir, 9(1).

Kamalludin, I., \& Arief, B. N. (2018). Kebijakan Reformasi Maqâshid alSyarîah dan Kontribusinya dalam Formulasi Alternatif Keringanan Pidana Penjara. Al-'Adalah, 15(1), 181-218.

Maulidi, Paradigma Progresif dan Maqashid Syariah: Manhaj Baru Menemukan Hukum Responsif, Jurnal Ilmu Syari'ah dan Hukum, Vol.49, No.2, Desember (2015): (Sekolah Tinggi Ilmu Al-Qur'an An-Nur Yogyakarta), 259. Diakses pada 25 Mei, 2021. file:/ / / :/Users/hp/AppData/Local/Temp/141-279-1-SM.pdf

Quyumi, Elfi dan Moh Alimansur. Upaya Pencegahan Dengan Kepatuhan Dalam Pencegahan Penularan Covid-19 Pada Relawan Covid. JPH RECODE. Oktober (2020); 4 (1): 81-87.

Rahmasari, F. S. (2020). Pengawasan Narapidana Pembebasan Bersyarat oleh Pembimbing Kemasyarakatan-Tantangan dan Alternatif Penyelesaiannya. JUSTITIA: Jurnal Ilmu Hukum Dan Humaniora, 7(2), 368-379. https:/ / core.ac.uk/download/pdf/322504347.pdf

Rizky, B. (2020). Dampak Positif Kebijakan Asimilasi dan Integrasi Bagi Narapidana Dalam Pencegahan Dan Penaggulangan Covid-19. JUSTITIA: Jurnal Ilmu Hukum Dan Humaniora, 7(3), 655-665.

Saputra, C. S. (2021). Analisis Kebijakan Asimilasi Bagi Anak di Masa Pandemi Covid-19 Menurut Perspektif Peraturan Kementerian Hukum dan HAM Nomor 10 Tahun 2020. DINAMIKA, 27(17). http://www.akrabjuara.com/index.php/akrabjuara/article/view/9 19

Trisnawati, Niyan Ati. Pemberian Asimilasi dan Integrasi Terhadap narapidana dan anak dalam pencegahan dan penanggulangan penyebaran covid-19, Jurnal ilmiah Hukum vol.26, No.14 (2020)

Umronah, E. (2020). Analisis Yuridis Pengawasan Asimilasi dan Integrasi Bagi Narapidana Dan Anak Ketika Pandemi Covid-19, (2020). Diakses $\begin{array}{llll}\text { pada } & 10 & \text { November }\end{array}$ file:/ / / :/Users/hp/AppData/Local/Temp/1554-3641-1-PB.pdf

\section{Majalah}

Shidiq, G. (2018). Teori Maqashid al-Syari'ah dalam Hukum Islam. Sultan Agung. 


\section{Internet}

Wibowo, A. (2020). Presiden Tetapkan Covid-19 sebagai Bencana Nasional. Badan Nasional Penanggulangan Bencana. http://bnpb.go.id/berita/presiden-tetapkan-covid-19-sebagaibencana-nasional.

\section{Peraturan Perundang-Undangan}

Peraturan Menteri Hukum dan Hak Asasi Manusia Nomor 21 Tahun 2013 tentang Syarat dan Tata Cara Pemberian Remisi, Asimilasi, Cuti Mengunjungi Keluarga, Pembebasan Bersyarat, Cuti Menjelang Bebas dan Cuti Bersyarat.

Peraturan Menteri Hukum dan Hak Asasi Manusia Nomor 10 Tahun 2020 tentang Syarat dan Tata Cara Pemberian Asimilasi, Pembebasan Bersyarat, Cuti Menjelang Bebas, dan Cuti Bersyarat bagi Narapidana dan Anak dalam Rangka Pencegahan Penyebaran Covid-19.

Peraturan Menteri Hukum dan Hak Asasi Manusia Nomor 32 Tahun 2020 tentang Syarat dan Tata Cara Pemberian Asimilasi, Pembebasan Bersyarat, Cuti Menjelang Bebas, dan Cuti Bersyarat bagi Narapidana dan Anak dalam Rangka Pencegahan Penyebaran Covid-19. 
Nor Kholifatur Rosyidah dan Aristoni

Halaman ini sengaja dikosongkan 